\section{Re-imagining the Indian state: External forces and the transformation of telecommunications policy, I 947-present}

Global Media and Communication $1-19$

(C) The Author(s) 2018 Reprints and permissions: sagepub.co.uk/journalsPermissions.nav DOI: I0.II77/I7427665I8759794 journals.sagepub.com/home/gmc

@SAGE

\author{
Colin Agur \\ University of Minnesota-Twin Cities, USA
}

\begin{abstract}
This article examines Indian telecom policy from independence to the present. Dividing this period into three phases - from 1947 to 1984, 1984 to 199I and 1991 to the present - the article explores the role of the state in India's dramatic transformation from a telecommunications laggard to one of the world's largest markets in mobile communication. It draws on a wide range of government documents, institutional surveys (domestic and international) of Indian telephony, memoirs and analyses by policy officials, and interviews with telecom executives. This article makes two arguments. First, it emphasizes the importance of external forces, including economic pressures, obligations to foreign creditors and the arrival of outsiders into key policymaking positions. Second, it provides an alternative to the simplistic argument that the state has 'left telecommunications to the private sector'. Rather than abandon its role in network building and maintenance, the Indian government has deployed its power in specific and deliberate ways. While much of this policy development was unanticipated and at times accidental, Indian telephony has been transformed from an inward-looking and defensive statist monopoly to an internationalized, technocratic marketplace.
\end{abstract}

\title{
Keywords
}

India, mobile communication, policy, telecommunications

\footnotetext{
Corresponding author:

Colin Agur, Hubbard School of Journalism \& Mass Communication, University of Minnesota-Twin Cities, I I I Murphy Hall, 206 Church Street SE, Minneapolis, MN 55408, USA.

Email: cpagur@umn.edu
} 
This article examines Indian telecommunications policy from Independence in 1947 to the present, highlights changes in the country's approach to telecommunications and emphasizes the role of outside forces (economic and technological) in India's policy shift. The article divides this period into three phases. The first lasted from Independence to the early 1980s. During this phase, India remained a laggard in the construction of telephone networks and the development of computing technology. The second phase began in 1984, with the arrival of Rajiv Gandhi (a former airline pilot) as Prime Minister and the return to India of Sam Pitroda, a computer engineer and telecommunications entrepreneur. During this phase, the government funded the Centre for the Development of Telematics (C-DoT) and other initiatives intended to foster software and hardware expertise inside the country and announced ambitious plans to connect the country via telephone networks. The third and most significant phase began in the early to mid1990s, with India's balance of payments crisis and externally induced liberalization in the telecom sector. Throughout the remainder of the 1990s and in the decade that followed, the Indian government passed far-reaching legislation that increased the role of private operators in the emerging mobile telecom market while maintaining government control over licensing and spectrum allocation. The results of this most recent phase in policymaking have been rapid and sustained growth in mobile phone connectivity, a competitive market and the growth of a handful of Indian telecom giants with large overseas operations.

A quick read of this history might suggest a retreat by the state from a sector in which it had once held a monopoly, and a relaxing of state efforts to control the market. To some extent, these claims hold true. But this article contends that the liberalization narrative belies a lingering set of controls by state actors, including insider deals on licences, punitive government actions and favouritism towards the state telecom provider, in pursuit of certain economic, social and political objectives. Examining the shift that has taken place - in policymaking and institutional development - this article finds that exogenous factors played significant roles in India opening its telecommunications market and in its adoption of a competitive and internationally oriented approach to telecommunications policy. By focusing on the political economy and players in the process, this article is distinct from more technical histories of network expansion, such as Subramanian (2014).

This article is the result of a mixed methods approach. In addition to textual sources - including government documents, institutional surveys (domestic and international) of Indian telephony, memoirs and analyses by policy officials - the article also draws on a series of interviews with major figures in India's telecom sector. These interviews took place in Delhi, Gurugram, Mumbai, Pune and Chennai, in person and by phone. The interviews lasted 45 minutes on average and were semi-structured conversations; the questions focused on each interviewee's experience with India's telecom reforms. Frequent topics included the following: expertise in policymaking, changes in expectations and behaviour of institutions, expected and unexpected challenges, and corruption. The interviewees cited in this article include the following: the chief financial officer (CFO) of a major mobile service provider, the CEO of a cellular tower company, the vice-president of a telephone technology provider, an executive at a network hardware firm and an IT (information technology) consultant in the telecommunications sector. As 
in Parthasarathy (2004), these interviews offer inside perspectives from people who have experienced India's telecommunication policy shift, seen its institutions evolve and dealt with the ensuing challenges and opportunities. By drawing on these interviews, this article seeks to go beyond the story provided by official documents and legislation.

\section{Independence and India's telephone network}

Following India's independence in 1947, the government of Prime Minister Jawaharlal Nehru sought to impose socialist policies on the British-built communication networks that the country inherited. Strongly influenced by Nehru's emphasis on collective interests before personal profit and by Gandhi's vision of swaraj (self-rule/self-reliance), national telecommunications policies excluded private and foreign operators and sought to Indianize the colonial infrastructure the state had taken over from the departing British. Nehru and Gandhi differed in their beliefs about how to achieve modernization, but they shared a belief that India could chart its own path and be 'modern without being Western' (Prakash, 1999: 231). At the time, many policymakers believed that directing funds towards landline expansion would upset the drive for social equity and foster resentment. When India gained independence, the new country had fewer than 100,000 telephones, 321 telephone exchanges (concentrated in five cities) and 338 long-distance public call offices for a population of more than 300 million people (Department of Telecommunications, Ministry of Communications and Information Technology, Government of India, 1987: 2). In a country of few telephone connections, public call offices (phone booths shared by a neighbourhood) provided connectivity and social interaction in cities and towns across India. The Development of Telematics (DoT) gave public call office licences to discharged soldiers, who built other businesses (often fruit or vegetable stands) around them. Despite the success of public call offices, India's telephone network development was hampered by several factors - unlike certain unions and heavy industries, telephony lacked a champion who could inspire greater investment in the network. There was little money, public or private, invested in telephone R\&D. And from independence until the 1980s, government policy treated telephones as a luxury; officials from the DoT stated that 'subscribers should return their telephones if they did not think their service was satisfactory' (McDowell, 1997: 134).

The telecommunications bureaucracy did not connect many Indians by telephone, but it created manufacturing jobs in disadvantaged areas and offered the national government a steady source of revenue. The DoT imported (and later built its own) switchboards, manufactured and owned telephones (which it rented to the public), built and maintained telephone lines, provided connectivity, administered wait lists, regulated the industry (which was largely an exercise in self-regulation), planned future development, and offered advice to the government on the role telecommunications should play in Indian society (Bardhan, 1984; Bhagwati, 1993; Chowdary, 1999). As Subramanian (2008) states,

There was no shortage of lip service provided by politicians who clearly saw the potential of telecommunications to national, especially the development of India's nearly 600,000 villages, where $70 \%$ of the population lived. But real developments were woefully short in coming. (p. 36) 
For the first two decades after Independence, India's telephone network remained tiny compared with the large and still-growing post and telegraph networks. A few numbers are suggestive: in 1964, Indian Posts and Telegraphs maintained nearly 90,000 offices and carried nearly 5 billion items in the mail - 10 items per Indian citizen. That same year, Indian Railways carried an average of 500,000 passengers per day. Meanwhile, the telephone network included fewer than 600,000 phones - one per 800 citizens (Government of India, 1964: 307, 329, 332). Moreover, the telephone network was more geographically concentrated than the rail or telegraph network. The relatively few telephone exchanges that did exist connected wealthy urban users, with 90 per cent of the phones in the hands of 10 per cent of the population (Ravi, 1994).

India was one of many low-income former colonies with poor telephony in the early 1980s, promoting the International Telecommunications Union (ITU) to appoint the Maitland Commission with a mandate to study and recommend policy options. The Commission's report, published in 1984, identified the tendency of low-income and (especially) newly independent countries to pursue a statist developmental agenda in pursuit of social objectives, at times to the detriment of greater efficiency and commercial possibilities in telephony (ITU, 1985: 37-42). The Commission's report went beyond merely describing a well-known problem; it provided a multifaceted prescription for network development. It made the case for structural reform of public telephone monopolies. It called for R\&D focused on requirements (often environmental and climactic) specific to low-income countries, emphasizing the need for indigenously produced technology. In doing so, it identified India and a handful of other 'special cases' with the potential to create telecommunications research institutes and achieve excellence in manufacturing equipment. The report stated that in India's case, the potential use of telephony was illustrated by the measured benefits enjoyed by those few who had access to telephony: in villages, the economic return on long-distance public telephones had been five times the cost of the call, even taking into account the time lost from work and bus fare to the calling booth (ITU, 1985: 9). The Maitland report argued that if India made telephone connectivity a higher priority, it would enjoy significant economic and social development far greater than the cost of network expansion.

In the early 1980s, India lagged behind other low-income countries in key indicators of development in telephony. In a country with nearly 700 million people, slightly more than 2 million phone lines existed in total. The national tele-density rate $^{1}$ of 0.3 per cent placed India below most other low-income countries across Asia and Africa (Panagariya, 2008: 372). In vast swaths of rural India, telephone service was non-existent, since it had not expanded beyond business and governmental elites in urban centres. India's 'national' telephone network could more accurately be described as a handful of localized networks largely disconnected from each other. Many rural Indians lived far from trunk lines, others lacked the right connections to move up the long wait lists and even among wealthy consumers, service was spotty even for those lucky enough to own a phone. Customers faced long and preferential waiting lists for equipment, poor service quality and a severely limited network (Athreya, 1996: 11-13; Jeffrey and Doron, 2013: 32-37).

While the number of connected telephones grew slowly, the bureaucracy serving them expanded significantly. The DoT contained a uniquely Indian 'Brahmanic socialism', 
with senior officials drawn from the high castes and a large number of lower positions reserved for marginalized castes, religious minorities and tribal groups (Bardhan, 1984: 58). This created a bottom-heavy organization and a sharp divide between the high administrators and engineers, and the low operators, mechanics, casual labourers and office assistants. The government's neglect of connectivity in favour of employment led to a dysfunctional bureaucracy and low public esteem of the DoT (Desai, 2006: 37-41). Gurcharan Das (2000) described service quality and official attitudes towards telephone availability as follows:

The telephones that existed were not dependable - it was rare to get a number on the first attempt. The employees of the telephone department were arrogant and corrupt. If the lines were down, it could take months to fix unless one bribed the linesmen. When an MP complained in Parliament of these breakdowns [...] Mrs. Gandhi's communications minister replied that telephones were a luxury, not a right, and that $[\ldots]$ there was an eight-year waiting list for this 'broken-down product'. (p. 208)

These problems reveal both the limited ambition the Indian government had for telephones and the low-quality statism pervasive in the Department of Telecommunications. In the six decades following Independence, the Indian government consolidated statist control of the telephone network and established large institutions to manage it, but did little to expand the network, improve service or prioritize telephony as part of postcolonial statecraft. Instead, the telephone network was held back by a corporatist approach to economic and social development that kept telephones scarce and unreliable. National policies - ostensibly to favour the poor and unions - discouraged luxury goods (including the telephone) and curtailed imports of foreign electronics.

\section{The statist origins of India's mobile revolution}

During her 1980-1984 mandate, a mix of economic and political pressure led Prime Minister Indira Gandhi to make major changes in telephone policy. The 1980 election of Ronald Reagan was followed soon after by declining aid from the United Sates to India. This exacerbated other problems India faced (including a gas crisis and balance of payments). At the same time, the government endured growing criticism of telephone connectivity and service. With an eye towards technological development and frustrated middle class voters, Gandhi relaxed import restrictions on communications equipment, expanded the national television network and deregulated the advertising industry. ${ }^{2}$ In 1981, she appointed the Sarin Committee with a mandate to assess India's telephone management. Its key recommendations - splitting the Post and Telegraph Department into two autonomous units and allowing greater imports of telephone equipment - faced bureaucratic resistance; not until 1985-1986 did these changes take place in practice (Athreya, 1996: 11-13).

In 1984, the government created the C-DoT to develop indigenous technologies and private manufacturing of customer premise equipment. A major aim was to build small rural exchanges and improve tele-density levels in the vast and under-serviced rural parts of India. Its immediate goals were to develop a small rugged switch that would 
work in India's tropical heat, and an advanced large switch capable of handling 40,000 lines. The high quality and low cost of switches helped them proliferate in villages throughout the late 1980s (C-DoT, Government of India, 2015a, 2015b, 2015c). Certainly, India had a problem with scarcity of telephone equipment in the 1980s and C-DoT provided some relief as the decade drew to a close. With these moves, India's telecommunications and computing sectors reduced their dependency on imported equipment (Meemamsi, 1993; Singh, 1999).

The arrival of Rajiv Gandhi as Prime Minister in 1984 changed both the style and substance of the government's approach to telecommunications. His government made telecommunications one of six mission areas in science and technology and promoted developments in computing and connectivity. In hindsight, we can see that the Rajiv era inspired some of the technical and political developments that needed to occur for the reforms of the 1990s to be possible. Three major parts of this development were the division of the Post and Telecom monopoly, the encouragement of new networks and the diffusion of telecommunications elites beyond Delhi. The younger Gandhi deregulated the computer industry and created a Software Technology Park in Bengaluru to encourage the development of an export-oriented software industry. During the Rajiv years, television penetration quadrupled to more than 200 million, and the government promoted the idea that India could engage in 'leapfrog' development, skipping stages in industrial development on the way to an information revolution. Crucially, telephony was rededicated from a luxury to a national priority and included as one of six science and technology 'mission' areas for the government (Sharma, 2009).

In 1984, another outsider entered India's policymaking discussions and soon made his presence felt. Sam Pitroda, a non-resident Indian businessman who had enjoyed success in US telephony and computing, returned to India and quickly became a major player in the country's burgeoning IT sector (Chhaya, 1992: 105-53). Pitroda became a close associate of Rajiv Gandhi; placed in charge of the Telecom Mission, Pitroda sought to improve quality of service in urban areas, extend connections in rural areas and computerize government agencies. In his words, government policy took the view that telecommunications 'played an indispensable role in promoting openness, accessibility, accountability, connectivity, democracy, and decentralization - all the "soft" qualities so essential to effective social, economic, and political development' (Pitroda, 1993: 68). Pitroda (1993) championed a techno-populism that sought to use communication networks to empower the poor and enrich the country's democracy:

as a great social leveler, information technology ranks second only to death. It can raze cultural barriers, overwhelm economic inequalities, even compensate for intellectual disparities. In short, high technology can put unequal human beings on an equal footing, and that makes it the most potent democratizing tool ever devised. (p. 66)

Despite the rhetoric of telephony for the poor, in practice, government policies served a narrow swath of Indians in the middle class (and above) who wanted telephony for business purposes. Advertisements for the Indian telephone service promoted the device as an accessory for a high-income, upper-caste lifestyle (Saxena, 2009: 26). Some critics pointed out that despite the good intentions of this statist agenda, the discourse of 'taking 
technology to the people' reflected an older elite bias that 'had little or no contact with the basic social reality that constitutes India' (Kothari, 1989: 12-17). What Rajiv Gandhi, Sam Pitroda and their allies saw as the future of India, opposition parties and traditionalists dismissed as a 'yuppie fascination with technology' (Bhagwati, 1993: 97).

To pursue the goals identified by the Telecom Mission, Rajiv Gandhi's government made two major steps (Athreya, 1996; Chowdary, 1998). The first was in provision of equipment. In 1985, the government allowed private firms to manufacture and sell phones across the country and initiated a scheme to have entrepreneurs manage for-profit subscriber trunk dialling (STD) ${ }^{3}$ booths with equipment supplied by the DoT and profits divided between the entrepreneurs and the DoT (Mody, 1995; Panagariya, 2008: 373). STD booths proliferated across the country, offering customers more reliable service that had been the case under the old public call offices managed by the Post and Telegraph Department. The government's attention to the problem of equipment scarcity led to the early entry of private players at local levels of telephone management. This had an expansionary effect, providing many villages with cheaper and better connectivity, and many others with their introduction to telephony. The government's second major step came in mobile technology. The impetus had initially come from the DoT, which, in 1987, announced efforts to create a cellular network in Mumbai. The network would have been managed collaboratively by the Swedish equipment manufacturer, Ericsson, and the DoT, giving the former a small but certain-to-grow market and the latter a golden opportunity to develop new capacities in telephone organization and technology. But, it faced opposition from some key players, especially Pitroda and was killed by politics (Chakravartty, 2004: 243).

The technological enthusiasm that pervaded Rajiv Gandhi's government lent itself to ambitious goals and mixed outcomes. The growth rate for telephony remained above the 7 per cent mark throughout the 1980s, but India still struggled to connect many of its citizens; at the decade's end, barely 5 million phones existed in India, of which more than 3 million were considered 'outdated instruments'. Meanwhile, the waiting list for telephone connections was still four times the supply of installed lines (Panagariya, 2008: 372). Two institutional factors explain the government's struggle to connect the country. First, economic rent-seeking by the DoT resulted in a telephone bureaucracy that paid more than 300,000 workers but allocated little funding for network expansion (Mukherji, 2008). Second, India's policy framework contained a legal bias towards the status quo, with no provision for new entrants or an independent regulator to check the power of the DoT. Policy analyst Bella Mody writes that as in many Third World countries, India had 'no disinterested non-governmental organizations to advise [...] on telecommunication technology' (Mody et al., 1993: 270). The DoT owned the networks and equipment, provided service, regulated that service and provided (often self-serving) recommendations to the government.

In the late 1980s, India's telephone network struggled amid corporatist politics, vested interests and bureaucratic inertia. Symptomatic of these forces was Swamy's Treatise on Telephone Rules, the official guide to India's telephone monopoly. The 1989 edition included more than 700 pages of bureaucratic rules and procedures pertaining to the acquisition, operation and maintenance of a government-owned telephone (Muthuswamy and Brinda, 1989). 


\section{Liberalization and national mobile networks (1990-present)}

India's telephone networks became the source of controversy and contentious debate in the 1990s. Between 1991 and 1999, Indian telephony experienced a policy overhaul, the formation of new institutions, bitter disputes in court, massive construction of infrastructure and rapid expansion of new mobile phone networks across the country. Initially forced (by external economic events) to accept the liberalization of its telephone sector, the government underwent a philosophical shift on the significance of telephony. As a result of this shift, a series of governments (led by three different political parties) implemented sweeping changes in telephone policy, with new goals of economic and social development.

\section{Crisis and change in Indian policymaking}

In the summer of 1991, a series of major political and economic events fundamentally altered India's governance of telephony. In May, former Prime Minister Rajiv Gandhi, who had been ousted from office 2 years earlier, was assassinated by a suicide bomber. The Congress Party quickly chose PV Narasimha Rao as replacement leader; he won the election several weeks later. When Rao took office, he faced an acute economic crisis. Several years of fiscal deficits had increased the Indian government's cost of borrowing and the shock of high oil prices from the Gulf War had led to a devaluation of the Indian rupee and depleted most of the country's foreign exchange reserves (Cerra and Saxena, 2002). With 3 weeks of cash reserves remaining, the new government approached the International Monetary Fund (IMF) for assistance. Although the crisis had not been caused by India's tight regulatory structure (the 'Licence Raj'), as part of its IMF bailout, the Indian government was nevertheless forced to make sweeping changes in how it managed several sectors, including telecommunications (Desai, 2006: 45-47; Sinha, 2001). Prime Minister Rao appointed Dr Manmohan Singh, a respected economist, as Finance Minister and gave him the task of liberalizing India's economy.

The Rao government's commitment to liberalization extended far beyond the resolution of the crisis. When the Athreya Committee published a series of pro-market recommendations, the Department of Telecommunication dismissed them as interference from foreign consultants (Desai, 2006: 45-46; Athreya, 1991). But the new government found much it liked in the Committee's recommendations. In 1994, the Rao government emphasized private sector involvement in telephony as part of its New Economic Policy. In this policy and in reforms focused on telephony, a pattern emerged: the Prime Minister's Office and the Ministry of Finance pushed for reform, while the Department of Telecommunications largely resisted change.

In 1994, the Rao government announced its plans to pass new legislation to enlarge and enhance telephone service. The National Telecom Policy (NTP 94) laid out a vision of vastly improved telephony for the country. Key objectives included making telephones available on demand, making India a major manufacturing base for telephone equipment, establishing telephone connections to all villages and providing higher quality service at low prices (Lok Sabha, Government of India, 1994). NTP 94 set specific 
targets for the provision of public phones, telephone connections to villages and total telephone lines in the country. It also set forth the broad goals of providing 'world standard' service with the 'widest possible range' of telephony options to users in urban and rural areas. The policy allowed new entrants to provide basic mobile telephone services as supplements to the DoT while maintaining the DoT's status as sole provider of longdistance service (Hossain, 1998: 213-223).

NTP 94 acknowledged that the government alone could not meet key targets and explicitly recognized that private investment and private sector involvement would need to play a new and significant role. Private sector participation took place first in valueadded services such as paging and cellular services, and then in landlines. The DoT kept its monopoly in landline services and let new private entrants compete for the uncertain mobile service market. The government held a competitive bidding process and issued licences to private operators in the four metros (Delhi, Mumbai, Kolkata and Chennai) as well as in all the states (Desai, 2006: 47-49). The bidding process began in 1992 and became a protracted struggle. As the incumbent in the market, the DoT had an interest in delaying the arrival of private operators and in hindering their ability to succeed. Soon, it became apparent that the DoT had used hidden criteria to select bidding firms, and a 1994 court ruling found in favour of the DoT on the grounds that no existing piece of legislation prohibited such a move (Supreme Court of India, 1994: 4947-50). The DoT selected the winning bids and, in the summer of 1995, cellular service began in the four metro circles; 3 years later, nearly all cellular operators with licences had begun operations. Basic services in landlines took longer because, unlike in mobile markets, the landline market had been under government control and the DoT had much to lose if it faced competition.

The initial reforms (1991-1995) had taken place under a government led by the Congress Party, which had historically resisted free trade and private sector involvement in telecommunications. When the more free-market-oriented Bharatiya Janata Party (BJP) formed a government from 1998 onwards, telecommunications liberalization ranked high on the government agenda. The government's creation of a high-level committee to develop Internet services led to an expanded set of responsibilities for the committee - within a year, it had initiated what would become an even larger and more sophisticated series of reforms in telecommunications policy. In 1999, the Vajpayee government announced the NTP 99. NTP 99 was an attempt to rectify some of the problems in NTP 94 and take a large step toward improving India's still-lagging tele-density. The earlier policy had acknowledged the need for greater private sector participation, but much implementation was delayed due to policy mis-steps (pricing the licences beyond the level of revenues private mobile operators could expect) or political wrangling. It removed some of the small, costly details left in NTP 94, such as the provision that the last mile linkage be composed of copper (Singh et al., 2000: 7).

NTP 99 was more than just a policy do-over; it was a genuinely new and more wideranging policy document. It sped up competition in data and domestic long distance. It emphasized the role of R\&D in developing world-class equipment manufacturing. It clarified rules on the number of licences an operator could hold at any time. It opened up voice and data service to 100 per cent foreign ownership. Perhaps, most noteworthy about NTP 99 over NTP 94 is the long-range nature of its provisions. It proposed uniform 
20 year licences for both basic and mobile services, with extensions of 5 years extending to 10 years. It emphasized the need for modern, efficient infrastructure and considered the challenges and opportunities of convergence in IT, media, telephony and consumer electronics. It also set out a vision on a range of related issues including standardization, training and human resources (HR) development, and disaster management (Lok Sabha, Government of India, 1999). An important step in NTP 99 was a new national revenuesharing regime. Under this regime, all mobile service providers pay a small upfront fee upon entry to the market, and from that point forward, they pay a percentage of their revenues to the government. NTP 99 recognized the problems of high fees and overly optimistic revenue estimates for mobile operators, and the resulting debt crisis some faced after a few years of operation. To lessen their debt burden and make them more competitive, existing mobile operators were allowed to pay a fixed sum to the government and were then switched to the new revenue-sharing model (Department of Telecommunications, Ministry of Communications and Information Technology, Government of India, 2015; Jain, 2001).

The implementation of NTP 99 capped off a transformative decade in Indian policymaking in telecommunications. Just as striking as the policy changes themselves are the changing reasons for this transformation. In 1991, the Indian government was forcedby economic circumstances and by the conditions of its IMF bailout - to adopt a new philosophy of governance in telecommunications. By 1999, the government had moved from reactive to deliberate liberalization of its telecommunications. During this crucial decade, a series of governments (led by three different political parties) implemented increasingly ambitious policy decisions, with far-reaching goals. These included connectivity and economic/social development, integrating India into the global information society and making the transition from an agrarian and largely rural economy to industrial and service economy centred in increasingly connected cities. In the early $1990 \mathrm{~s}$, the question of liberalization provoked bitter disagreement among players in the telephone sector. By the decade's end, at the level of elite policymakers, something approaching a consensus had emerged: India would need to leave behind its corporatist past in telephony and embrace a new model of network development.

\section{Growth and growing pains in India's mobile networks}

In the years since NTP 99, India's telephone networks have grown in spectacular fashion. Table 1 shows that even in a country with a large population and high growth rate, mobile phone networks have spread with remarkable speed since the reforms of the 1990s.

In addition to the number of phones in use, other statistics give a similar sense of the country's network expansion. Today, India has more than 400,000 cellular towers dotting the landscape; by comparison, the United States has roughly half as many towers covering a much larger geographical expanse (Steel in the Air, 2015). From humble infrastructural beginnings, India's telephone network has grown into a massive set of networks stretching across the country.

Given the government's tight financial position and the scale of the efforts necessary to liberalize telephony, the policy reforms emphasized the need for private sector involvement (Lok Sabha, Government of India, 1999: 2). To construct a national telephone 
Table I. Telephone adoption in India.

\begin{tabular}{llll}
\hline Year & Indian population & Telephones in use & Teledensity (phones per I00 citizens) \\
\hline 1947 & $340,000,000$ & 100,000 & 0.029 \\
1964 & $464,000,000$ & 580,000 & 0.125 \\
1984 & $728,000,000$ & $2,00,000$ & 0.357 \\
1991 & $842,000,000$ & $5,100,000$ & 0.606 \\
2001 & $1,036,000,000$ & $37,000,000$ & 3.571 \\
2011 & $1,240,000,000$ & $900,500,000$ & 72.581 \\
2015 & $1,280,000,000$ & $1,002,000,000$ & 79.670 \\
\hline
\end{tabular}

Sources: Statistical Outline of India (2014); Government of India (1947-present); Cellular Operators Association of India, National Telecom Statistics, 2005-present; Telecommunications Regulatory Authority of India (TRAI, 20I I-present), Telecom Subscription Data; TRAI (20I2).

network, India needed towers, cables, switches, exchanges, satellites, and other network infrastructure (Jeffrey and Doron, 2013: 35). Even after the Indian government had recovered from the 1991 crisis, it did not have the capital to build this network infrastructure. In addition to this shortage of fiscal capital, the government also recognized its limits in human capital. Although the DoT had some 300,000 employees on its payroll, it did not contain the specialized workforce necessary to expand and manage the network (Interview, executive at a network hardware firm, 2013).

More than financial or human capital, India needed new institutions. Initially, DoT executives resisted the government's efforts to divide the DoT into separate organizations for policymaking and the provision of telephone services. To protest the planned division of the DoT into two parts, in September 2000, more than 300,000 workers, represented by the National Federation of Telecom Employees (NFTE) and the Federation of National Telecom Organization (FNTO), went on strike, paralyzing India's IT sector. After receiving reassurances from Prime Minister AB Vajpayee that their jobs would remain secure after the split, the two unions called off the strike (Donald, 2000). In October 2000, the government created a new arms-length institution (Bharat Sanchar Nigam Limited, or BSNL) to take control of the DoT's telephone service.

The expansion of India's telephone networks required not just new actors and institutions but also an entirely new political economy. To regulate the sector and raise capital, the DoT established a licensing model. With each new standard in mobile phone technology, the DoT held a series of sales of licences and spectrum. The early years of private sector involvement involved considerable uncertainty over the economic value of the networks and how much companies should be asked to pay for licences and spectrum. To regulate a market composed of multiple players, the DoT divided the country into 20 licensing 'circles' of different shapes, sizes, and populations; in 1994, the Indian government opened bidding for licences in each circle, with service to commence in the summer of 1995. The results were messy: some licence circles received a high number of bids while others received none, some firms won rights to more circles than they were capable of serving, and some losing firms complained of preferential treatment during the bidding process (Dokeniya, 1999; Dossani, 2002; McDowell and Lee, 2003; Singh, 
1999). Initially, the private service providers paid high prices for licences and spectrum on the assumption that they would be able to swiftly amortize their investments and take advantage of a rapidly growing national mobile network. During 1995-1998, it became clear that these companies would not be able to reach their revenue targets and, as a result, several new entrants found themselves with unsustainable debt levels (Desai, 2006; Jain and Sridhar, 2003: 56).

Creating a new political economy was easier said than done, and several factors led to a dysfunctional arrangement in the late 1990s. The first factor was the hostile relationship that quickly developed between private firms and the DoT. After decades as an unchallenged monopoly, the DoT faced direct competition from new entrants who had none of the legacy costs (in infrastructure and personnel) left to the DoT. To protect itself, the DoT attempted to retain control of the more profitable elements of the telephone market, including international calling, and limit the profitability of new entrants by forcing private companies to use the legacy network and charging interconnection fees (Kathuria, 2000; Panagariya, 2008: 375-376). The second factor causing a dysfunctional political economy was the unclear power relationship that developed between the DoT and the newly formed regulator, the Telecommunications Regulatory Authority of India (TRAI). Initially the TRAI's mandate did not give it authority over the DoT: when the TRAI ruled against the DoT, the latter would invariably appeal to the Delhi High Court, which would invariably side with the DoT on the grounds that the Indian Telegraph Act of 1885 did not allow an independent regulator to supersede the licence-granting authority of the DoT. Private service providers resented what they saw as a regulator that could not regulate the then-largest player in Indian telephony.

To reduce the uncertainty surrounding the new regulatory agency's power, the TRAI Act was amended in the wake of NTP 99. The amended Act divided the regulatory and dispute settlement roles of the TRAI and established a new Telecom Disputes Settlement and Appellate Tribunal (TDSAT). With a direct line to the High Court (only it could overrule TRAI decisions), enhanced institutional legitimacy in law and in public perception, and greater protection from cabinet interference, the revamped dispute settlement process is safer from the politics that had frustrated TRAI effectiveness in its first 3 years. The amended Act also spelled out more explicitly TRAI responsibilities: it gained a mandate to provide recommendations on new service providers, technological improvements, quality standards, and the details of licence contracts (Lok Sabha, Government of India, 2000). Now more established, and backed up with greater legal force, the TRAI has emerged as an agency with regulatory teeth (CFO of a major mobile service provider, 2013).

To improve efficiency on India's early mobile networks, the major service providers made a series of decisions. First, they pursued a policy of shared access to infrastructure such as towers and chose not to charge each other for interconnection (Bhardwaj, 2013). Second, as the networks expanded and the construction and maintenance of infrastructure became a massive undertaking, the major service providers outsourced this work to specialized infrastructure firms. Third, later on, as labour costs began to rise, major service providers looked outside India and outsourced aspects of their operations. Over time, these actions by major players had two effects: they transformed the political economy of telephony in India and allowed for major network expansion (CFO of a major mobile service provider, 2013). 
Today, India's telephone networks are extensive but strained and not only because of phone usage itself. India's telephone network is dependent on two other national networks that remain inadequate to the growing mobile network-related tasks they are now required to perform. The first of these is electricity. Two-thirds of India's towers are connected to the electrical grid, but because of inconsistency in the electrical supply, more than 60 per cent of the power requirement for the country's mobile phone towers comes from gasoline or diesel. Such is the scale of India's mobile phone network that 1.8 billion litres of fuel are burned annually by generators that keep the country's towers operating (Global System for Mobile Communication Association, 2012; Greenpeace, 2011). India's towers - especially those off the electrical grid - are also dependent on a second network: India's roads. The maintenance of India's towers requires the delivery of fuel, spare parts, and personnel to conduct inspections and make repairs. All of this transportation adds to the already high usage of fuel and creates major vulnerabilities for the companies that own and operate the towers: these include changes in the world price of oil, inconsistencies in local supply and thieves who break into tower sheds to steal gasoline. In rural areas, towers are expensive to maintain and difficult to secure (CEO of a cellular tower company, 2013; Cellular Operators Association of India, 2014b).

In less than 20 years, India has been transformed from a society largely bereft of telephony to the second-largest telephone market in the world, measured by the number of users. A device that was once a rarity is now ubiquitous; the telephone has been woven into work, family life, leisure, politics, and criminal activity (Agur, 2015; Belair-Gagnon et al., 2013). And a country that was for nearly a century home to a lethargic telecom monopoly is now a major player in international mobile telephone service and in policymaking related to the Internet. India is still some distance from achieving universal service: because of the large number of users with multiple devices, the country's tele-density figures, therefore, exaggerate the level of penetration (Global System for Mobile Communication Association, 2012). Nevertheless, India's telephone networks are of orders of magnitude denser and more inclusive than when the reforms began in the early 1990s. In addition to these quantitative differences, we can identify qualitative differences in today's telephone networks. Today, India is home to new and increasingly ambitious governmental goals for the network, a rapidly expanding market of 900 million telephones and a homegrown international telephone giant, Bharti Airtel. In 1990, it seemed highly unlikely that India would become home to either the world's second-largest market or the world's third-largest mobile service provider (Jeffrey and Doron, 2013: 27-29).

But along with this change, we can point to continuity in today's telephone networks: there remains a wide disparity between haves and have-nots, and this disparity follows the same socio-economic and geographical divides that existed in previous periods of India's telecommunications history. Service providers construct network infrastructure in rural areas because they are required to (and paid to do so), not because they believe that rural network infrastructure will generate a short- or long-term payoff (Interview, vice-president of a telephone technology provider, 2013). In this sense, we see the continuation of certain hierarchies in Indian communication networks: during the colonial period, urban areas enjoyed the best service and cheapest rates of transmission and transport; today, with India's cellular networks growing and becoming more dense, urban 
areas enjoy better coverage and more service options than are available in rural parts of the country. Wealthy urban users also have greater access to $3 \mathrm{G}$ and $4 \mathrm{G}$ networks, which allow for large-scale data transmission, the integration of Internet service into smart phones, and a wide range of applications (Interview, executive at a network hardware firm, 2013). These geographical and economic hierarchies follow pre-existing communicative hierarchies that date back to the British-build colonial communication networks of the 19th and early 20 th centuries. This tendency has reinforced pre-existing design biases and given rise to a 'data divide' in mobile communications. If left unchecked, this divide may exacerbate existing levels of inequality and make national economic policymaking more difficult (Sridhar and Sridhar, 2009).

\section{Institutional ambition and corruption}

Since the 1990s, new and substantially larger telephone networks have created a new set of interactions among new institutions in India. Today, India's mobile networks contain a dynamic set of actors, including giant multinationals, medium-sized national companies and upstarts. In contrast to the oligopolies common in Western markets, India's mobile service market is hyper-competitive. As a result, for service providers, it offers low-profit margins - even for established major players with the densest networks, the most customers, the best engineers, extensive experience in Indian telephony and highlevel political contacts. The elimination of distance as a barrier in telephone connectivity and pricing has been good for users but removed one of the more profitable elements (long-distance calling) for telephone companies (Interview, vice-president of a telephone technology provider, 2013). And while India's mobile network infrastructure may be fragile and strained, its users have high expectations and little loyalty to the companies that provide service. This helps explain the difficulties telephone service providers and infrastructure firms have in turning profits (Interview, vice-president of a telephone technology provider, 2013; interview, CEO of a cellular tower company, 2013; interview, CFO of a major mobile service provider, 2013).

In addition to its service providers, India is now home to a growing array of specialized companies focused on some of the trickier aspects of network development and management. Initially, Indian telephone giants sought to integrate all aspects of network expansion into their business model: with economies of scale and scope, Bharti Airtel and Reliance tried to make their size part of their competitive advantage as institutions trying to dominate a new network. As they gained more customers and covered larger swaths of the country, these companies found that managing telephone networks involved expertise well beyond that of managing telephony itself (Interview, CEO of a cellular tower company, 2013). Rather than concentrate a range of experts in-house and attempt to guard them from rivals, the larger telephone service providers realized the benefits of outsourcing (Interview, IT consultant in the telecommunications sector, 2013). This has turned on its head the logic that a single company (or, in the case of the old DoT, a government department) can or should handle all aspects of telephony.

While India has jettisoned many aspects of poor governance, it retains another in the form of widespread corruption. The most spectacular example of corruption among elites came during the scandal that resulted from the $2 \mathrm{G}$ licensing and spectrum sale in 2008 . 
Telecommunications Minister A Raja chose not to conduct an open auction; instead, he used a first-come-first-served sale, with the selling date mysteriously moved up by a week without public notice. Many would-be bidders were caught unprepared by the sudden change in dates. Meanwhile, a few companies had no trouble making the new deadline; some even had applications dated prior to the announced date change, suggesting that their executives had been privy to the scheduling change before the information was made public (The Economist, 2012). The DoT sold 122 licences (one-third of the national total) at prices based on assumptions from 2001 and collected a total of Rs 12,386 crore (US\$2.8 billion) from successful bidders (Jain, 2001; Swamy, 2012; Thakurta, 2012). This was a dramatic under-sale of a significant government asset. In its investigation of the scandal, India's Comptroller and Auditor General (CAG) revalued the $2 \mathrm{G}$ spectrum and licences using several benchmarks, with its highest assessment coming in at Rs 176,645 crore (US $\$ 40$ billion), some 15 times the revenue the 2008 sale yielded the government (Comptroller and Auditor General of India, 2010: 51-56). As a result of the scandal, A Raja and others involved in the scandal were sent to prison on corruption charges, all 122 licences from the sale were declared invalid, and the ruling Congress Party vowed to keep a closer eye on the DoT (Central Bureau of Investigation, 2012).

The $2 \mathrm{G}$ spectrum scandal revealed the power the DoT retained even after losing many of its former functions: a decade after the entry of private service providers and more than 5 years after the arrival of an empowered, independent regulator (TRAI), the DoT still played a central role in the 'new' political economy of Indian telephone networks. In the years since the $2 \mathrm{G}$ scandal, the government (via Parliament, TRAI, the CAG, and the Supreme Court) has created institutional checks on telephone elites, prompting complaints from some of pre-emptive punitive treatment (Interview, CEO of a cellular tower company, 2013).

Given the continued role of state actors, it would be simplistic to say that the state has 'left telecommunications to the private sector'. Rather than abandon its role in network building and maintenance, the Indian government has learned to deploy its power in specific and deliberate ways. Belatedly and unexpectedly, India's government has developed ambition and competence as a network-builder. Part of the explanation is situational: telephony is precisely the sort of nationalistic and technocratic project that a post-colonial government can champion. Some of it is also evolutionary: India's new institutions have learned to co-exist and share governance of the new networks. The scale of Indian mobile telephony is now so significant that no one institution could govern the entire apparatus (Interview, executive at a network hardware firm, 2013). And a crucial part of it was exogenous: telecommunications policy was influenced by a series of external forces, including economic pressures, obligations to foreign creditors and the arrival of outsiders in key policymaking positions.

\section{Conclusion: Continuity and change in India's communication networks}

This article has charted the history of India's telephone network through three periods: the corporatism that followed Independence, the quiet change that took place in the 1980s, and the reforms and dramatic market expansion since 1990. In doing so, it has 
sought to uncover long-term patterns in India's telecommunications. One such pattern is the continued presence of the Indian state as a major shaper of India's telecommunications sector. Rather than retreat, the government has instead redeployed its power. Once it had navigated the crisis of the early 1990s, it became proactive about policy change. It determined the scope and speed of reforms, established a licensing model and a mechanism for spectrum allocation, oversaw the creation of new institutions and new initiatives and - crucially - chose to maintain a presence in the provision of telephone services. Collectively, these actions show not the absence of statism in contemporary Indian telecommunications, but, instead, a different and - in some ways, more ambitious - set of efforts by Indian state institutions to shape telecommunications in the 21 st century.

This renewed statism did not happen on its own. It was the result of a series of forces that forced open the previously closed policymaking process. The arrival of Rajiv Gandhi and Sam Pitroda in senior roles, the exogenous shock of the economic crisis in 1991 and subsequent pressure by international creditors, and the arrival of foreign technology and - eventually - foreign telephone service providers are each owed some credit for the transformation of India's telecommunications policy. In this sense, the new statism that has characterized Indian telephony owes its existence not to political will or some economic inevitability but to a combination of unforeseen and even accidental forces in governance.

\section{Funding}

The author(s) received no financial support for the research, authorship, and/or publication of this article.

\section{Notes}

1. The tele-density rate is the number of telephones per 100 inhabitants.

2. These included the MTNL (Delhi and Mumbai), the Development of Telematics (DoT, rest of India), and the VSNL (international).

3. Subscriber trunk dialling (STD) dates back to the 1950s in the United Kingdom and the United States (where it is known as Direct Distance Dialing (DDD)). STD/DDD allows a telephone user to place a call to a number outside the local network without operator assistance, using regional or national calling codes dialed in advance of the phone number.

\section{ORCID iD}

Colin Agur iD https://orcid.org/0000-0003-0799-6691

\section{References}

Agur C (2015) Second-order networks, gambling and corruption on Indian mobile phone networks. Media, Culture \& Society 37(5): 768-783.

Athreya MB (1991) Report of the High Level Committee on Reorganisation of Telecom Department. New Delhi, India: Indian Government Publications and Athreya Committee.

Athreya MB (1996) India's telecommunications policy: A paradigm shift. Telecommunications Policy 20(1): 11-22.

Bardhan P (1984) The Political Economy of Development in India. New Delhi, India: Oxford University Press. 
Belair-Gagnon V, Mishra S and Agur C (2013) Reconstructing the Indian public sphere: Newswork and social media in the Delhi gang rape case. Journalism 15(8): 1059-1075.

Bhagwati J (1993) India in Transition: Freeing the Economy. Oxford: Clarendon Press.

Bhardwaj S (2013) Infrastructure sharing in telecom industry: Growth of new business models and their prospective trends. International Journal of Research and Development 2(1): 20-24.

Cellular Operators Association of India (2014a) National telecom statistics. Available at: www. coai.com/Statistics/Telecom-Statistics/National (accessed October 2016)

Cellular Operators Association of India (2014b) Rural subscriber figure report. Available at: www. coai.com/Statistics/Rural-Subscriber-Figure-Report (accessed October 2016)

Central Bureau of Investigation (2012) Anti-corruption board report on 2G spectrum scam.

Centre for Development of Telematics (C-DoT), Government of India (2015a) Brief history. Available at: www.cdot.co.in (accessed October 2016)

Centre for Development of Telematics (C-DoT), Government of India (2015b) Current focus. Available at: www.cdot.co.in (accessed October 2016)

Centre for Development of Telematics (C-DoT), Government of India (2015c) Vision, mission, and objectives. Available at: www.cdot.co.in (accessed October 2016)

Cerra V and Saxena SC (2002) What caused the 1991 currency crisis in India? International Monetary Fund Staff Papers 49. Available at: www.imf.org/external/pubs/ft/staffp/2002/03/ pdf/cerra.pdf (accessed October 2016)

Chakravartty P (2004) Telecom, national development and the Indian state: A postcolonial critique. Media, Culture \& Society 26(2): 232-233.

Chhaya M (1992) Sam Pitroda: A Biography. New Delhi, India: Konark Publishers.

Chowdary TH (1998) Politics and economics of telecom liberalization in India. Telecommunications Policy 221: 9-20.

Chowdary TH (1999) Telecom De-Monopolisation in India. Hyderabad, India: Center for Telecom Management Studies Publication.

Comptroller and Auditor General of India (2010) Performance audit report on the by the Department of Telecommunications. Available at: http://www.cag.gov.in/content/report-no-19-2010-performance-audit-issue-licences-and-allocation-2g-spectrum-union (accessed October 2016)

Das G (2000) India Unbound: A Personal Account of a Social and Economic Revolution. New York: Knopf.

Department of Telecommunications, Ministry of Communications and Information Technology, Government of India (1987) Forty Years of Telecommunications in Independent India. New Delhi, India: Department of Telecommunication.

Department of Telecommunications, Ministry of Communications and Information Technology, Government of India (2017) Cellular mobile telephone service. Available at: http://www.dot. gov.in/telecom-glance (accessed October 2016).

Desai AV (2006) India's Telecommunications Industry. New Delhi, India: Sage.

Dokeniya A (1999) Re-forming the state: Telecom liberalization in India. Telecommunications Policy 23: 105-128.

Donald A (2000) India says strike-hit telecoms services restored. Financial Times, 22 September.

Dossani R (2002) Telecommunications reform in India. India Review 1(2): 61-90.

The Economist (2012) Megahurts. The Economist, 11 February. Available at: http://www.economist.com/node/21547280.

Global System for Mobile Communication Association (2012) The true cost of providing energy to telecom towers. White Paper. Available at: www.gsma.com/membership/wp-content/ uploads/2013/01/true-cost-providing-energy-telecom-towers-india.pdf (accessed October 2016)

Government of India (1947-present) India: A Reference Annual. New Delhi, India: Publications Division, Government of India. 
Greenpeace (2011) Dirty talking? The case for telecom to shift from diesel to renewable. Available at: www.greenpeace.org/india/Global/india/docs/cool-it/reports/telecom-reportmay-2011.pdf (accessed October 2016)

Hossain H (1998) Liberalization and privatization: India's telecommunications reform. In: Hossain $\mathrm{M}$ and Malbon J (eds) Who Benefits from Privatization? London and New York: Routledge, pp.213-223.

International Telecommunications Union (ITU) (1985) The Missing Link: Report of the Independent Commission for World Wide Telecommunications Development. Geneva: ITU.

Jain P and Sridhar V (2003) Analysis of competition and market structure of basic telecommunication services in India. Communications \& Strategies 52(4): 271-293.

Jain R (2001) Cellular Licensing in India. Indian Institute of Management (Ahmedabad) Working Paper, Indian Institute of Management, Ahmedabad, India.

Jeffrey R and Doron A (2013) The Great Indian Phone Book. London: Hurst and Co.

Kathuria R (2000) Telecom policy reforms in India. Global Business Review 1(2): 301-326.

Kothari R (1989) The Problem: The Technology Missions, Seminar 354, February 1989: 12-17.

Lok Sabha, Government of India (1994) National telecom policy. Available at: http://www.dot. gov.in/national-telecom-policy-1994

Lok Sabha, Government of India (1999) New telecom policy. Available at: www.trai/gov.in/ Content/ntp_1999.aspx (accessed October 2016)

Lok Sabha, Government of India (2000) Amendment to the telecommunications regulatory authority of India act. Available at: http://www.trai.gov.in/sites/default/files/The_TRAI (Amendment)_Act_2000.pdf

McDowell S (1997) Globalization, Liberalization and Policy Change: A Political Economy of India's Communications Sector. New York: St. Martin's Press.

McDowell SD and Lee J (2003) India's experiments in mobile licensing. Telecommunications Policy 27(5-6): 371-382.

Meemamsi GB (1993) The C-Dot Story. New Delhi, India: Kedar Publications.

Mody B (1995) State consolidation through liberalization of telecom. Journal of Communication 45(4): 107-124.

Mody B, Bernt PW and Weiss MBH (1993) Telecommunication privatization in the periphery: Adjusting the private-public balance. International Review of Comparative Public Policy 5: 257-274.

Mukherji R (2008) The Politics of telecommunications regulation: State-industry alliance favoring Foreign investment in India. Journal of Development Studies 44(10): 1405-1423.

Muthuswamy and Brinda (eds) (1989) Swamy's Treatise on Telephone Rules with Act, Rules, Orders, Digest, Guidelines \& Case-Law. Madras, India: Sawmy's Publishers.

Panagariya A (2008) India: The Emerging Giant. New York: Oxford University Press.

Parthasarathy B (2004) Globalizing information technology: The domestic policy context for India's software production and exports. Iterations: An Interdisciplinary Journal of Software History 3: 1-38.

Pitroda S (1993) Development, democracy and the village telephone. Harvard Business Review 71(6): 66-79.

Prakash G (1999) Another Reason: Science and the Imagination of Modern India. Princeton, NJ: Princeton University Press.

Ravi N (1994) Telecommunications in India. IEEE Communications Magazine 30: 24-29.

Saxena SD (2009) Connecting India: Indian Telecom Story. New Delhi, India: Konark Publishers.

Sharma DC (2009) The Long Revolution: The Birth and Growth of India's IT Industry. New Delhi, India: HarperCollins. 
Singh HV, Soni A and Kathuria R (2000) Telecom Policy Reform in India (Working Paper). Washington, DC: World Bank.

Singh JP (1999) Leapfrogging Development? The Political Economy of Telecommunications Restructuring. New York: SUNY Press.

Sinha N (2001) State transformation and India's telecommunication reform. In: Waisbord SR and Nancy M (eds) Media and Globlization: Why the State Matters. Lanham, MD: Rowman \& Littlefield, pp.55-76.

Sridhar Kala Seetharam and Varadharajan Sridhar (2009). Telecommunications Infrastructure and Economic Growth: Evidence from Developing Countries. National Institute of Public Finance and Policy, Working Paper \#14.

Statistical Outline of India (2014) Statistical Outline of India. Mumbai, India: Tata Services.

Steel in the Air (2015) Market statistics. Available at: www.steelintheair.com (accessed October 2016)

Subramanian D (2014) From monopoly power to deregulated markets: The travails of a stateowned firm (ITI Ltd). Contributions to Indian Sociology 48(1): 73-102.

Subramanian R (2008) The (continuing) evolution of India's telecom policy. Communications of the International Information Management Association (CIIMA) 8(3): 33-48.

Supreme Court of India (1994) Tata Cellular vs Union of India (Civil Appeal, no. 4947-50, 26 July). New Delhi, India: Supreme Court of India.

Swamy S (2012) 2 G Spectrum Scam. New Delhi, India: Har Anand.

Thakurta PG (2012) The Great Indian Telecom Robbery. Documentary film. Chennai, India: Stanford India Development Group.

Telecommunications Regulatory Authority of India (2012) Telecom sector in India: A decadal profile. Available at: www.trai.gov.in/WriteReadData/Publication/Document/20130412105 2403536675NCAER-Report08june12.pdf (accessed October 2016)

Telecommunications Regulatory Authority of India (2011-present) Telecom subscription data. Telecommunications Regulatory Authority of India. Available at: http://www.trai.gov.in/ release-publication/reports/telecom-subscriptions-reports

\section{Author biography}

Colin Agur is an assistant professor at the Hubbard School of Journalism and Mass Communication at the University of Minnesota - Twin Cities. His research examines contemporary mobile phone usage, the social and legal implications of mass mobile telephony, and the unanticipated consequences of network development. At the International Communication Association (ICA), he is Chair of the Mobile Communication Interest Group. He has held research fellowships at the Institute for Advanced Study (IAS) at the University of Minnesota and the Tow Center for Digital Journalism at Columbia University. Prior to coming to the University of Minnesota, he was a postdoctoral fellow in media and law at Yale Law School's Information Society Project. In 2014, he received his $\mathrm{PhD}$ in Communications from Columbia University's Graduate School of Journalism. 